\title{
Evaluating functional diversity conservation for freshwater fishes resulting from terrestrial protected areas
}

\author{
Karl A. Lamothe ${ }^{1}\left(\mathbb{D} \mid\right.$ Karen M. Alofs ${ }^{2}$ | Cindy Chu ${ }^{3,4}$
}

${ }^{1}$ Great Lakes Laboratory for Fisheries and Aquatic Sciences, Fisheries and Oceans Canada, Burlington, ON, Canada

${ }^{2}$ School for Environment and Sustainability, University of Michigan, Ann Arbor, MI, USA

${ }^{3}$ Aquatic Research and Monitoring Section, Ontario Ministry of Natural Resources and Forestry, Peterborough, ON, Canada

${ }^{4}$ Department of Ecology and Evolutionary Biology, University of Toronto, Toronto, ON, Canada

\section{Correspondence}

Karl A. Lamothe, Great Lakes Laboratory for Fisheries and Aquatic Sciences, Fisheries and Oceans Canada, 867 Lakeshore Road, Burlington, ON, Canada.

Email: karl.lamothe@dfo-mpo.gc.ca

\section{Abstract}

1. Protected areas are one of the hammers in conservation toolkits, yet few protected areas exist that were designed to protect freshwater ecosystems. This is problematic as freshwater ecosystems are among the most threatened systems on earth. Nonetheless, terrestrial protected areas (TPAs) may afford spill-over benefits to freshwater ecosystems included within their boundaries, but evaluations of these potential benefits for the protection of freshwater fish diversity are lacking.

2. Using fish community data from 175 lakes inside, outside, or bordering TPAs in Ontario, Canada, we sought to determine if TPAs preserve fish functional diversity. We focused on functional diversity because previous work indicated no taxonomic differences between these lakes, but a difference in normalised-length size-spectra slopes inside versus outside TPAs (indicator of unique predator-prey ratios and trophic energy transfer). We expected that communities inside TPAs would show greater functional diversity (i.e. functional dispersion and functional richness) and have more extreme trait combinations (i.e. functional divergence) than communities outside or bordering TPAs. We also tested for differences in the rarity of species-specific functional traits between fish communities inside, outside, or bordering TPAs, between thermal guilds, and across average body size and overall prevalence of the species.

3. Our results indicated no significant differences in functional diversity among lake fish communities inside, outside, or bordering TPAs. However, fish communities inside TPAs had more extreme trait combinations than outside TPAs because abundant species in lake communities outside TPAs had more ubiquitous trait combinations than abundant fishes inside TPAs.

4. Small-bodied species showed greater functional rarity than large-bodied species, indicating that small-bodied fishes fill functionally unique roles while the most prevalent, large-bodied species possess a more generalist set of traits.

5. Overall, the similarity of functional diversity metrics for lake fish communities inside, outside, or bordering TPAs in Ontario suggests that TPAs capture the functional diversity of Ontario's lake fish communities. However, we encourage similar evaluations in regions where environmental conditions and stressors are more distinct across TPA boundaries than they are in Ontario, as these types of evaluations will inform guidelines for the design of freshwater protected areas and monitoring of their effectiveness in the future. 


\section{1 | INTRODUCTION}

Freshwater ecosystems provide society with many ecosystem services such as safe drinking water, food, and places for recreation (Aylward et al., 2005); however, they are also among the most threatened on our planet (Carpenter, Stanley, \& Vander Zanden, 2011; Dudgeon, 2014; Dudgeon et al., 2006; Reid et al., 2019), risking the delivery of these services to society. Examples of the disturbances impacting freshwater ecosystems include physical and chemical habitat degradation (Arthington, Dulvy, Gladstone, \& Winfield, 2016; Dugan et al., 2017; Smith, Tilman, \& Nekola, 1999), invasive species (Dextrase \& Mandrak, 2006), microplastics (EerkesMedrano, Thompson, \& Aldridge, 2015), and global climate change (Myers et al., 2017; Poesch, Chavarie, Chu, Pandit, \& Tonn, 2016). These disturbances can interact and their effects can accumulate in downstream systems (Jackson, Loewen, Vinebrooke, \& Chimimba, 2016; Nõges et al., 2016; Schindler, 2001). As a result, extinction rates of freshwater biota are estimated to be 112-855 times higher than rates for terrestrial species (Collen et al., 2014; Tedesco et al., 2017). For example, between 1896 and 2006, 57 North American freshwater fish species went extinct (Burkhead, 2012) and, in Canada, 71 of the 207 native fish species are considered at risk by the Committee on the Status of Endangered Wildlife in Canada (Dextrase \& Mandrak, 2006; Lamothe et al., In press). As such, improvements to the protection of freshwater ecosystems and continued restoration are needed to sustain future freshwater ecosystem services provisioning.

The need to protect and conserve freshwater ecosystems is particularly relevant in Canada, which contains approximately $7 \%$ of all the renewable liquid freshwater (i.e. lakes and streams) on Earth (Environment and Climate Change Canada, 2017a). Protection of this resource is primarily achieved through federal legislation related to environmental protection (e.g. Canada Water Act; Government of Canada, 1985a), fisheries (e.g. Fisheries Act; Government of Canada, $1985 \mathrm{~b}$ ), and protection of species at risk of extinction (Species at Risk Act; Government of Canada, 2002). Additionally, terrestrial protected areas (TPAs), or areas where the land and water are protected for the purpose of conserving nature (Environment and Climate Change Canada, 2017b), can provide protection for freshwater ecosystems (Dudley, 2008). For example, areas within TPAs have been shown to have more species than areas outside of TPAs (Gray et al., 2016) and their designation can lead to fewer anthropogenic disturbances in an area (Bruner, Gullison, Rice, \& de Fonseca, 2001). However, due to the connectivity of freshwater ecosystems, occurrence of freshwater species within TPAs does not necessarily imply protection (Harrison et al., 2016; Pimm et al., 2014).

Compared to terrestrial organisms, there have been relatively few studies investigating the degree of protection TPAs may provide freshwater fishes. Chu, Ellis, and de Kerckhove (2018) recently demonstrated no statistically significant differences in species-level diversity (i.e. Shannon's index) or catch-per-unit effort (CPUE) between fish communities inside, bordering, or outside TPAs in Ontario, Canada. However, CPUE and species diversity were generally higher inside TPAs than outside. In addition, the normalised-length sizespectra slopes, an indicator of predator-prey ratios and trophicenergy transfer of fish communities, were significantly steeper in fish communities outside TPAs compared to communities situated inside TPAs. This difference in size spectra slope was attributed to a greater abundance (albeit statistically insignificant) of small-bodied, pollution and turbidity tolerant species in lakes outside TPAs and differences in turbidity and angling pressure in lakes outside versus inside TPAs. Chu et al. (2018) concluded that taxonomic indicators may not be the most useful indicators for evaluating the effectiveness of TPAs for protecting freshwater ecosystems.

In some cases, traditional taxonomic-based diversity metrics fail to respond to changes in community structure resulting from environmental disturbances, for example, in the case of species invasions (Sagouis, Jabot, \& Argillier, 2016). As such, incorporating multiple diversity metrics into conservation strategies can provide a more robust and systematic framework for conservation resource allocation (Strecker, Olden, Whittier, \& Paukert, 2011). Functional diversity metrics, for example, relate the characteristics of individuals or species to the structures and functions of ecosystems and have been used to identify mechanisms of biodiversity loss (Cardinale et al., 2012) and vulnerability of biotic communities to future disturbance (Lamothe, Alofs, Jackson, \& Somers, 2018; Mouillot et al., 2014). Recent research suggests that although extinction rates for riverine fishes are on the rise, functional diversity at the river-basin scale has increased by approximately $150 \%$ because of the introduction of non-native species and their unique functional characteristics that were historically absent, particularly in low-diversity systems (Toussaint et al., 2018).

Few studies have explored the effectiveness of conservation programmes for protecting functional diversity and the relative degree of protection that TPAs provide to freshwater fish species. Britton et al. (2017) found that cichlid communities in water adjacent to TPAs had more herbivorous and specialist species, and more similar fish assemblages than areas farther from the TPAs. Similarly, Wilkinson, Yeo, Tan, Fikri, and Ewers (2018) found greater local fish functional richness in headwater streams surrounded by protected areas compared to streams coursing through logged forests or oil-palm plantations. As such, our objectives were to determine if TPAs preserve functional diversity of lake fish communities by comparing community-level and species-specific functional diversity metrics between fish communities in lakes inside, outside, and bordering TPAs. We expected that functional diversity (i.e. functional 
dispersion and functional richness) may be more sensitive than taxonomic diversity (examined by Chu et al., 2018). Given sufficient time since protection and stress outside of protected areas, we expected fish communities inside TPAs to show greater functional diversity than communities outside or bordering TPAs. Further, given the recent findings of Toussaint et al. (2018), we expected higher functional divergence (i.e. more extreme trait combinations) outside TPAs compared to lake communities inside or bordering TPAs.

\section{2 | METHODS}

\section{1 | Study lakes}

Ontario, Canada spans a large geographic area, covering $>100$ million ha with approximately 250,000 freshwater lakes (Lester, Marshall, Armstrong, Dunlop, \& Ritchie, 2003). Four freshwater ecoregions are represented in Ontario (Figure 1; St. Lawrence, Laurentian Great Lakes, Southern Hudson Bay, and English-Winnipeg Lakes; Abell et al., 2008) with the Laurentian Great Lakes and St Lawrence ecoregions having the highest freshwater fish species richness in Canada (Chu, Minns, Lester, \& Mandrak, 2015). Fish species richness in Ontario lakes ranges from 113 species in southern lakes to fewer than 10 species in northern lakes (OMNRF, 2015). As with other north temperate regions of the world, species richness and productivity are influenced by post-glacial recolonisation, climate, lake morphometry, and water chemistry (Mandrak, 1995). Anthropogenic disturbances are greatest along the shorelines of the Great Lakes and decrease at higher latitudes with relatively pristine conditions in the central and northern regions of the province (Chu et al., 2015). There are currently 661 federal or provincial TPAs in Ontario that cover approximately $10 \%$ of the province (IUCN, UNEP-WCMC, 2016).
To control for the impacts of lake and regional environmental factors, which were not the focus of this study but are known to impact fish diversity and abundance (Chu, Lester, Giacomini, Shuter, \& Jackson, 2016), we paired lakes inside, bordering, and outside TPAs with similar abiotic characteristics. We used the database of paired lakes and their respective fish communities from Chu et al. (2018) to investigate differences in functional diversity characteristics inside, bordering, or outside TPAs (Figure 1). Inside lakes are completely contained inside a TPA, outside lakes are completely outside TPAs, and border lakes are those with part, but not all, of their shoreline inside a TPA. Lakes were paired using single-linkage nearest-neighbour cluster analysis based on total precipitation, growing-degree days above $5^{\circ} \mathrm{C}$, lake surface area, and mean depth (Table 1), followed by three tests of robustness to confirm pairing decisions (Chu et al., 2018). The selection process generated 40 pairs of lakes for inside-outside comparisons, 15 pairs of lakes for the inside-border comparisons, and 42 pairs of lakes for border-outside comparisons for a total of 194 lakes. However, 16 lakes were paired twice in either inside-outside, inside-border, or border-outside group, two were paired twice within the border-outside group, and one was paired twice in the border-inside group. Therefore, the number of unique lakes was 175 . Lake characteristics varied widely across the 175 study lakes, with total annual precipitation ranging from 679 to $1,135 \mathrm{~mm}$, growing degree days above $5^{\circ} \mathrm{C}$ from 1,234 to 2,218 , lake area from 33 to 17,402 ha, and mean depths from 1.1 to $40.1 \mathrm{~m}$.

\section{2 | Fish sampling}

Fishes were sampled using the Ontario Ministry of Natural Resources and Forestry's Broad-scale Monitoring for Inland Lakes protocol, which outlines standardised methods for sampling fishes, invertebrates, water quality, and angler activities across
FIGURE 1 Location of the 175 study lakes sampled to compare the functional diversity of fish assemblages in Ontario, Canada. Dark borders within Ontario demarcate the four freshwater ecoregions represented in the province

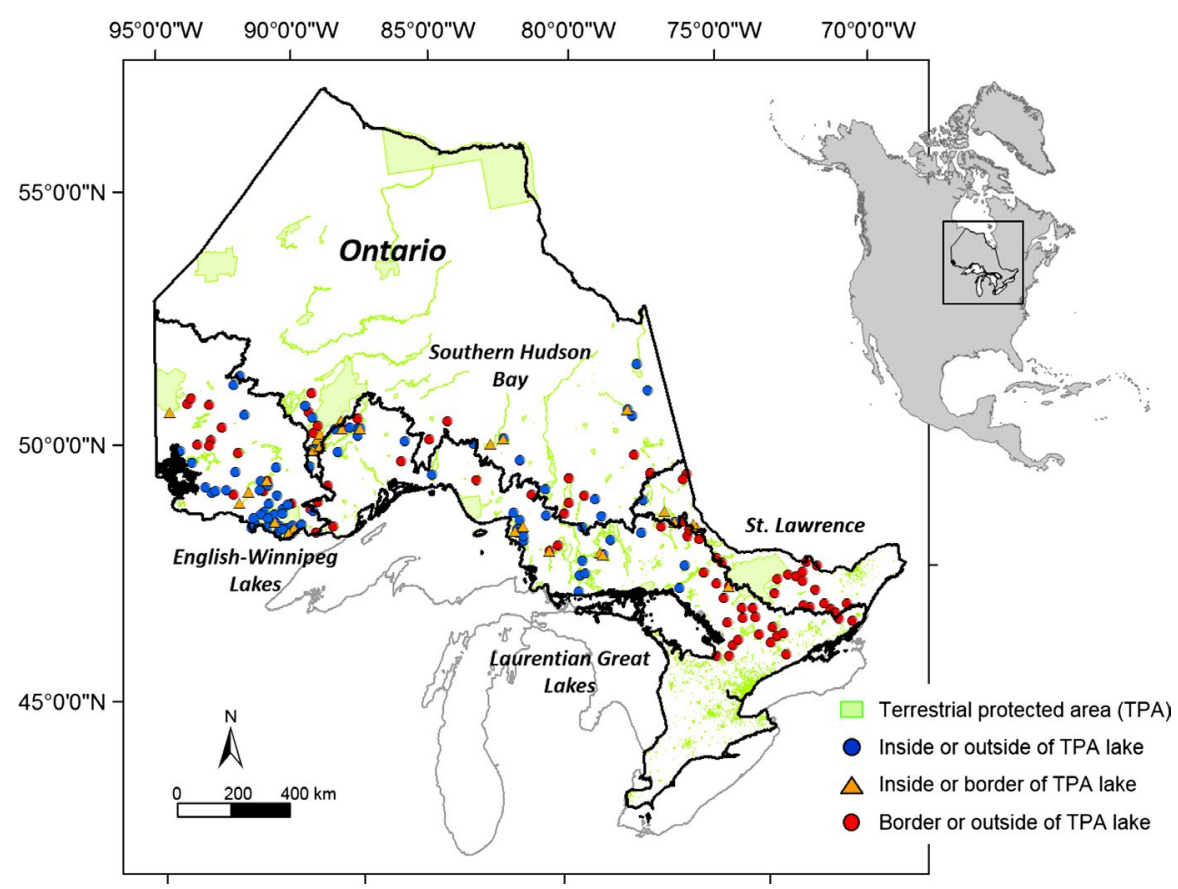


TAB LE 1 Lake characteristics and fish traits descriptions

$\begin{array}{lll} & \text { Units/ } & \\ & \text { Variable } & \\ \text { Variable } & \text { type } & \text { Description }\end{array}$

Lake characteristics

\begin{tabular}{|c|c|c|}
\hline Surface area & ha & Surface area of lake \\
\hline Mean depth & $\mathrm{m}$ & Mean depth of lake \\
\hline $\begin{array}{l}\text { Total } \\
\text { precipitation }\end{array}$ & $\mathrm{mm}$ & $\begin{array}{l}\text { Total precipitation based on } \\
1981-2010 \text { climate normals }\end{array}$ \\
\hline $\begin{array}{l}\text { Growing de- } \\
\text { gree days }\end{array}$ & Continuous & $\begin{array}{l}\text { Growing degree days above } 5^{\circ} \mathrm{C} \\
\text { based on } 1981-2010 \text { climate } \\
\text { normals }\end{array}$ \\
\hline TDS & $\mathrm{mg} / \mathrm{L}$ & $\begin{array}{l}\text { Concentration of total dissolved } \\
\text { solids }\end{array}$ \\
\hline Elevation & $\mathrm{m}$ & Mean elevation of lake \\
\hline \multicolumn{3}{|l|}{ Depth } \\
\hline Mean depth & $\mathrm{m}$ & $\begin{array}{l}\text { Mean depth of species in water } \\
\text { column }\end{array}$ \\
\hline $\begin{array}{l}\text { Maximum } \\
\text { depth }\end{array}$ & $\mathrm{m}$ & $\begin{array}{l}\text { Maximum depth of species in } \\
\text { water column }\end{array}$ \\
\hline $\begin{array}{l}\text { Minimum } \\
\text { depth }\end{array}$ & $\mathrm{m}$ & $\begin{array}{l}\text { Minimum depth of species in water } \\
\text { column }\end{array}$ \\
\hline \multicolumn{3}{|l|}{ Diet } \\
\hline Algae & Binary & $\begin{array}{l}\text { Feeds on algae, phytoplankton, or } \\
\text { filamentous algae }\end{array}$ \\
\hline Macrophyte & Binary & $\begin{array}{l}\text { Feeds on macrophytes and vascu- } \\
\text { lar plants }\end{array}$ \\
\hline Detritus & Binary & $\begin{array}{l}\text { Feeds on detritus or unidentifiable } \\
\text { vegetation }\end{array}$ \\
\hline Fish & Binary & Feeds on larger fish, crayfish, frogs \\
\hline Eggs & Binary & Feeds on eggs of fish, frogs, etc. \\
\hline \multicolumn{3}{|l|}{ Substrate } \\
\hline Muck & Binary & Associates with muck substrate \\
\hline Clay/silt & Binary & $\begin{array}{l}\text { Associates with clay or silt } \\
\text { substrates }\end{array}$ \\
\hline Sand & Binary & Associates with sand substrate \\
\hline Gravel & Binary & Associates with gravel substrate \\
\hline Cobble & Binary & Associates with cobble substrate \\
\hline Boulder & Binary & Associates with boulder substrate \\
\hline Bedrock & Binary & Associates with bedrock substrate \\
\hline \multicolumn{3}{|l|}{ Reproduction } \\
\hline Guarder & Binary & Guards or does not guard brood \\
\hline $\begin{array}{l}\text { Spawning } \\
\text { substrate }\end{array}$ & Binary & $\begin{array}{l}\text { Open substrate spawners vs hiding } \\
\text { or nesting }\end{array}$ \\
\hline
\end{tabular}

lakes (Sandstrom, Rawson, \& Lester, 2011). North American standard large-mesh multi-panel gill nets and Ontario standard smallmesh multi-panel gill nets were used to catch large-bodied (e.g. Lake Trout Salvelinus namaycush Salmonidae and Walleye Sander vitreus Percidae) and small-bodied fishes (e.g. Fathead Minnow Pimephales promelas Leuciscidae or juveniles of large-bodied species), respectively. Gill nets were set following a randomised, depth-stratified design for approximately 18-hr time intervals. Each sampled fish was identified to species, counted, and total lengths were measured.

\subsection{Functional trait space}

Fish trait variables $(n=17)$ were gathered from various sources (Coker, Portt, \& Minns, 2001; Eakins, 2017; Frimpong \& Angermeier, 2009; Holm, Mandrak, \& Burridge, 2009) to characterise the ecological niche of each species (Givan, Parravicini, Kulbicki, \& Belmaker, 2017; Lamothe, Alofs, et al., 2018) including components of the species' diet, modes of reproduction, substrate associations, and habitat-depth relationships (Table 1). Diet traits were sourced from the literature and included binary variables representing a preference for algae, phytoplankton, or filamentous algae, macrophytes and vascular plants, detritus, or unidentifiable vegetative matter, fish, crayfish, crabs, or frogs, and eggs of fish or other organisms (Frimpong \& Angermeier, 2009; Table 1). Mode of reproduction for each species was characterised by two binary variables based on whether fishes guard their brood and spawn on open substrate or hide or create nests for their brood (Table 1). Substrate associations included seven binary variables indicative of preferences for muck substrate, clay or silt substrate, sand substrate, gravel substrate, cobble substrate, boulder substrate, and bedrock (Table 1). Habitatdepth relationships were measured in the field and represent the depth at which species were caught including median depth, maximum depth, and minimum depth (Table 1). Finally, we calculated the average maximum total lengths $(\mathrm{mm})$ of the top $5 \%$ of individual fish captured per species after removing the top $2 \%$ (to remove any true or false giants that may skew the distribution), and we retrieved data on the thermal preference of species (cold water, cold/cool water, cool water, cool/warm water, and warm water; Coker et al., 2001) for post hoc comparisons.

To build the functional trait space, we first performed four PCAs to combine traits from within each of the four trait type categories (diet, substrate, habitat, and reproduction-Table 1 ) into respective trait dimensions (Lamothe, Alofs, et al., 2018). By combining the traits into their respective trait dimensions, we place similar weights on the various trait types when building the functional trait space. Hellinger transformations were performed on the trait data (Hubálek, 1982; Legendre \& Gallagher, 2001; Ochiai, 1957) and nontrivial axes were determined through permutation analysis (Peres-Neto, Jackson, \& Somers, 2003, 2005) where we permuted each column of the Hellinger-transformed species composition matrix and performed subsequent PCAs 9,999 times (Lamothe, Jackson, \& Somers, 2018). Axes were retained if the proportion of variance explained in the empirical data exceeded $95 \%$ of the permuted PCAs for that component. In total, one axis was extracted from each of the reproduction, diet, substrate, and habitat analyses, totalling four dimensions for each species. We then performed a principal coordinates analysis (PCoA) on the Euclidean distances of the four trait dimensions to define the functional trait space (Laliberté et al., 2010; Winemiller, Fitzgerald, Bower, \& Pianka, 2015). 


\subsection{Functional diversity metrics}

We calculated three functional diversity metrics for each fish community: functional dispersion (Anderson, 2006; Laliberté \& Legendre, 2010), functional richness (Mason, Mouillot, Lee, \& Wilson, 2005; Villéger, Mason, \& Mouillot, 2008), and functional divergence (Mason et al., 2005; Villéger et al., 2008). Functional dispersion is the average distance of each species in functional trait space to the centroid of all species in a community (Laliberté \& Legendre, 2010); greater functional dispersion indicates a more functionally diverse community. Functional dispersion was calculated using all available PCoA axes and was weighted by the relative CPUE of each species. Functional richness was calculated as the convex hull area of each community (Villéger et al., 2008), where greater functional richness indicates greater functional diversity. We calculated a convex hull area using the first two axes of the PCoA because one of the lakes in the analysis contained only three captured species, and therefore two is the maximum number of axes that allows for the number of species to be greater than the number of traits (Villéger et al., 2008). Finally, functional divergence describes the position of species relative to the border of the functional trait space (Villéger et al., 2008) and provides a measure of how the abundance of a community is distributed toward the extremities of occupied trait space (Mason et al., 2012; Mouchet, Villéger, Mason, \& Mouillot, 2010). Functional divergence approaches zero when abundant species are close to the centre of functional trait space and it approaches one when abundant species are distant from the centre of functional trait space (Mouillot, Villéger, Scherer-Lorenzen, \& Mason, 2011). Functional divergence should increase when niche complementarity enhances species' relative abundances (Mason et al., 2012).

We also calculated two species-specific measures of functional rarity from the Euclidean distance trait matrix: functional distinctiveness and functional uniqueness (Violle et al., 2017). Functional rarity describes the degree to which particular species possess traits that are rare or unique to the assemblage. Functional distinctiveness $(D)$ is calculated as the average distance of each species to all other species within a local community, whereas functional uniqueness $(U)$ describes the distance of each species to the nearest neighbour within the regional species pool (Buisson, Grenouillet, Villéger, Canal, \& Laffaile, 2013; Mouillot, Graham, Villéger, Mason, \& Bellwood, 2013; Violle et al., 2017).

\subsection{Statistical analyses}

We used paired $t$ tests to test for differences in functional dispersion, functional richness, and functional divergence between lakes inside versus outside TPAs, lakes inside versus bordering TPAs, and lakes bordering versus outside TPAs. Significance was assessed at $\alpha=0.01$ to account for multiple comparisons. Functional diversity can increase with species richness and saturation in this relationship has been used as an indicator of functional redundancy (Lamothe, Alofs, et al., 2018; Micheli \& Halpern, 2005). Therefore, we built generalised additive models to investigate the relationship between functional dispersion, functional richness, and functional divergence with species richness for lake communities inside, bordering, and outside TPAs following the procedures of Rose, Yang, Turner, and Simpson (2012). We fit interaction models of functional diversity as:

$$
y_{i j}=\alpha_{0}+\alpha_{1 j} \text { Category }_{i j}+f_{j}\left(R_{i}\right)+\varepsilon_{i}, \varepsilon_{i} \sim N\left(0, \sigma^{2}\right)
$$

where $\alpha_{0}$ is the model intercept, $\alpha_{1}$ is the difference between the mean response for the jth lake category (communities inside, bordering, or outside TPAs), $f_{j}()$ are centred, smooth functions of species richness $(R)$ for the jth lake category, and $\varepsilon$ are the Gaussian distributed residuals with mean 0 and variance $\sigma^{2}$. We compared the fitted smooth functions between lake categories by first building a prediction matrix $\mathbf{X}_{p}$ related to the fitted values of functional diversity $\left(\hat{y}_{p}\right)$ for a set of new data points $\mathbf{p}$. The rows of $\mathbf{X}_{\mathbf{p}}$ were then subtracted from one another for pairwise comparisons between lakes inside, outside, or bordering TPAs. Approximate 95\% confidence intervals for the differences between pairs of smooth functions were then generated and plotted (Rose et al., 2012); areas where the confidence interval overlaps zero indicates no pairwise difference in smooth functions between lake categories.

We used the FD (Laliberté \& Legendre, 2010; Laliberté, Legendre, \& Shipley, 2014), funrar (Grenié, Denelle, Tucker, Munoz, \& Violle, 2017), ggplot2 (Wickham, 2009), mgcv (Wood, 2004, 2006), and vegan (Oksanen et al., 2018) packages in the R Statistical Software (R Core Team, 2018) for graphing and analyses.

\section{3 | RESULTS}

\section{1 | Taxonomic diversity}

A total of 71 species were sampled from the study lakes (Table 2). Fishes of the Leuciscidae family (formerly Cyprinidae; Tan \& Armbruster, 2018) were the most prevalent family among the studied lakes with 19 species represented. On average, each lake contained $11.88 \pm 3.98$ SD species, with a minimum of three and a maximum of 24 species captured per lake (median: 12 species). Total CPUE per lake ranged from 11.72 to $1,478.52$.

\section{2 | Functional diversity}

Single axes were extracted from each of the reproduction, diet, substrate, and habitat PCAs, explaining 80.0, 40.9, 32.4, and $91.2 \%$ of the variation, respectively. To build our multidimensional functional trait space, two axes were extracted from a PCoA of the four PCA trait axes providing a moderate reduced-space quality $(59.0 \%$ of the total variation; Figure 2). Removing the single lake with three species (and its paired lake) from the analysis and using three PCoA axes to build trait space did not change our results but produced a higher quality functional trait space. We chose to include the three-species lake community in the analysis because three- and four-species lakes are common in the region. Fitting the PCA vectors to the PCoA 
TA B LE 2 Species captured across study lakes and their thermal preference group (Coker et al., 2001) and average maximum total length $(\mathrm{TL} ; \mathrm{cm})$ of the top $5 \%$ of individual fish captured per species after removing the top $2 \%$

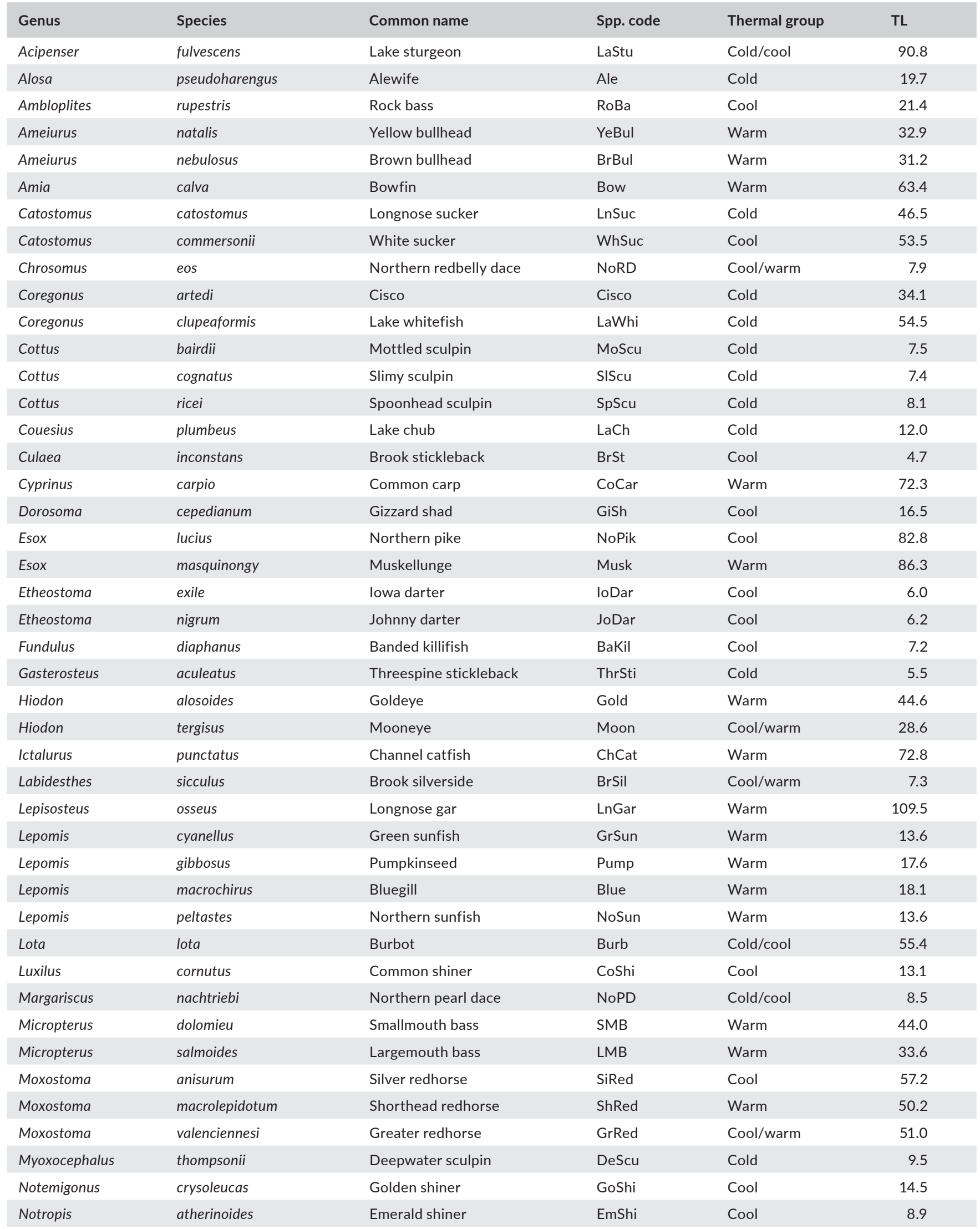


TABLE 2 (Continued)

\begin{tabular}{|c|c|c|c|c|c|}
\hline Genus & Species & Common name & Spp. code & Thermal group & $\mathrm{TL}$ \\
\hline Notropis & heterodon & Blackchin shiner & BcShi & Cool/warm & 6.5 \\
\hline Notropis & hudsonius & Spottail shiner & SpShi & Cold/cool & 9.4 \\
\hline Notropis & rubellus & Rosyface shiner & RoShi & Warm & 6.6 \\
\hline Notropis & volucellus & Mimic shiner & MiShi & Warm & 6.4 \\
\hline Oncorhynchus & mykiss & Rainbow trout & RaTro & Cold & 38.5 \\
\hline Oncorhynchus & tshawytscha & Chinook salmon & ChSal & Cold & 82.7 \\
\hline Osmerus & $\operatorname{mordax}$ & Rainbow smelt & RaSm & Cold & 14.9 \\
\hline Pimephales & notatus & Bluntnose minnow & BnMin & Warm & 7.3 \\
\hline Pimephales & promelas & Fathead minnow & FaMin & Warm & 7.7 \\
\hline Pomoxis & nigromaculatus & Black crappie & $\mathrm{BICra}$ & Cool & 24.7 \\
\hline Prosopium & cylindraceum & Round whitefish & RoWh & Cold & 36.7 \\
\hline Pungitius & pungitius & Ninespine stickleback & NiSti & Cold & 6.0 \\
\hline Rhinichthys & atratulus & Blacknose dace & BnDac & Cool & 4.7 \\
\hline Rhinichthys & cataractae & Longnose dace & LnDac & Cool & 7.3 \\
\hline Salvelinus & fontinalis & Brook trout & BrTro & Cold & 43.3 \\
\hline Salvelinus & namaycush & Lake trout & LaTro & Cold & 72.5 \\
\hline
\end{tabular}

Note: Temperatures defining the thermal groups are; cold $\left(<19^{\circ} \mathrm{C}\right)$, cool $\left(19-25^{\circ} \mathrm{C}\right)$, and warm $\left(>25^{\circ} \mathrm{C}\right)$ with cold/cool and cool/warm species having thermal preferences that straddle the boundaries.

biplot indicated that the first component was primarily related to habitat depth and reproduction traits while the second component was influenced by substrate and diet preferences (Figure 2).

There were no significant differences in functional dispersion or functional richness across pairwise comparisons of fish communities inside versus outside TPAs, inside versus bordering TPAs, or bordering versus outside TPAs (Table 3). However, fish communities inside TPAs had substantially higher functional divergence than fish communities outside TPAs, indicating that fish communities inside TPAs may show greater niche complementarity than communities outside TPAs.

No significant differences were found in the relationship between functional richness and species richness or functional divergence and species richness across pairwise comparisons of lakes that border TPAs, are inside TPAs, or are outside TPAs (Figures S1 and S2). In contrast, significant differences were observed in the relationships between functional dispersion and species richness (Figure 3a); lake communities outside TPAs showed significantly greater functional dispersion than lake communities bordering TPAs at species richness levels $<12$ and significantly lower functional dispersion at species richness $>12$ (Figure $3 c$ ). There were no differences in the functional dispersion and species richness relationship between lake communities inside versus outside TPAs (Figure 3b) or bordering versus inside TPAs (Figure 3d).

Species that were captured in the greatest number of lakes had the least distinct ( $\beta=-0.55 \pm 0.10$ SE; $t=-5.51, p<0.001$; Figure 4a) and least unique $(\beta=-0.14 \pm 0.05 \mathrm{SE} ; t=-2.65, p=0.01$; Figure $4 \mathrm{~d}$ ) ecological niches. Similarly, large-bodied species were less distinct $(\beta=-1.13 \pm 0.30 \mathrm{SE} ; t=-3.74, p<0.001$; Figure $4 \mathrm{~b})$ than small-bodied species, but there was no significant pattern observed between uniqueness and body size ( $\beta=-0.09 \pm 0.16 \mathrm{SE} ; t=-0.59, p=0.56$; Figure $4 \mathrm{e})$. Bridle shiner Notropis bifrenatus (Leuciscidae), threespine stickleback Gasterosteus aculeatus (Gasterosteidae), and green sunfish Lepomis cyanellus (Centrarchidae) showed the highest average functional rarity across rarity measures (i.e. uniqueness and distinctiveness; Figure 5) and were clustered on the negative end of the first functional trait space axis (Figure 2). Bridle shiner and green sunfish were only sampled inside 


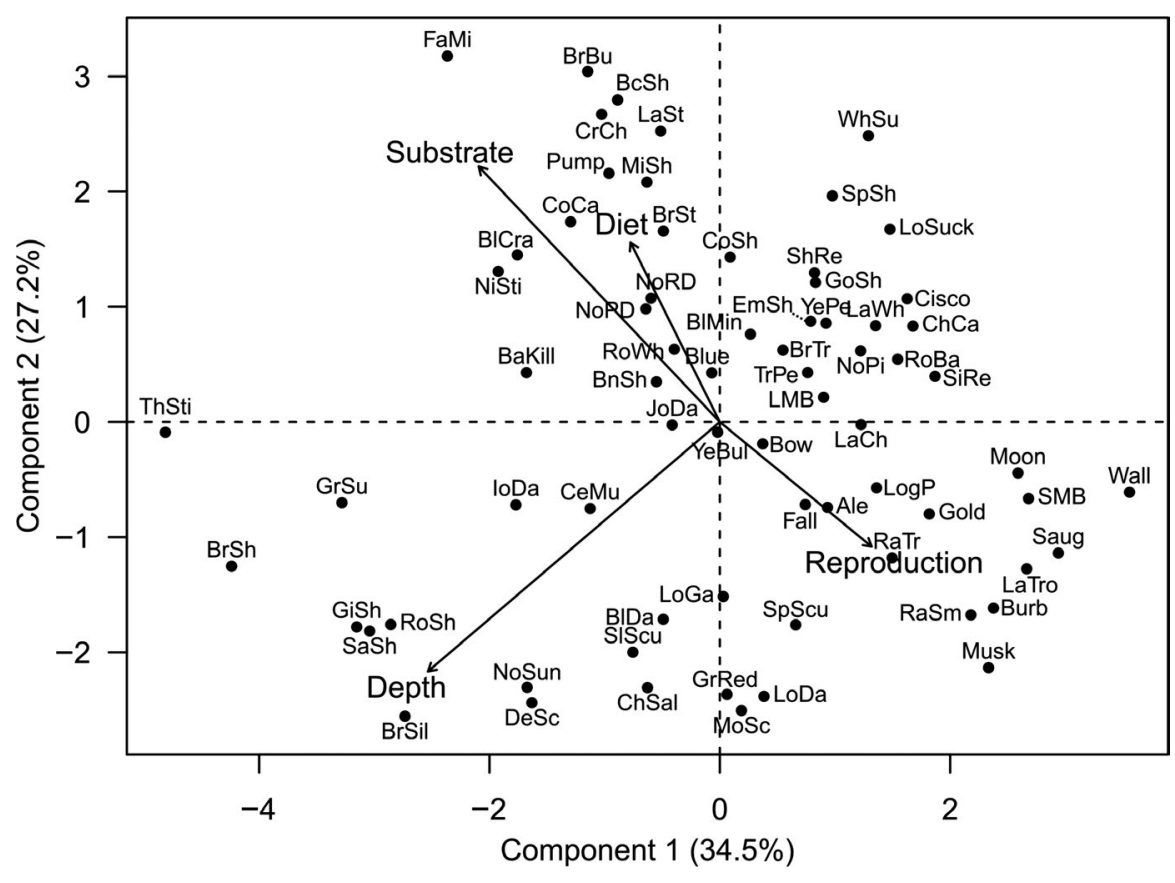

\begin{tabular}{|c|c|c|c|}
\hline & Functional dispersion & Functional divergence & Functional richness \\
\hline \multicolumn{4}{|c|}{ Inside versus outside $(n=40)$} \\
\hline $\begin{array}{l}\text { Mean inside } \\
(S D)\end{array}$ & $1.07(0.27)$ & $0.66(0.17)$ & $5.13(2.62)$ \\
\hline $\begin{array}{l}\text { Mean outside } \\
\text { (SD) }\end{array}$ & $0.96(0.26)$ & $0.60(0.15)$ & $5.59(2.97)$ \\
\hline $\begin{array}{l}\text { |Mean } \\
\text { difference| }\end{array}$ & 0.10 & 0.06 & 0.46 \\
\hline$|t|$ & 1.68 & 2.03 & 0.86 \\
\hline$p$-value & 0.10 & 0.05 & 0.40 \\
\hline \multicolumn{4}{|c|}{ Inside versus bordering $(n=15)$} \\
\hline $\begin{array}{l}\text { Mean inside } \\
\text { (SD) }\end{array}$ & $1.02(0.27)$ & $0.66(0.16)$ & $4.82(1.97)$ \\
\hline $\begin{array}{l}\text { Mean border- } \\
\text { ing (SD) }\end{array}$ & $1.06(0.27)$ & $0.67(0.10)$ & $5.43(2.41)$ \\
\hline $\begin{array}{l}\text { |Mean } \\
\text { difference| }\end{array}$ & 0.04 & 0.01 & 0.62 \\
\hline$|t|$ & 0.43 & 0.21 & 1.41 \\
\hline$p$-value & 0.67 & 0.84 & 0.18 \\
\hline \multicolumn{4}{|c|}{ Bordering versus outside $(n=42)$} \\
\hline $\begin{array}{l}\text { Mean border- } \\
\text { ing (SD) }\end{array}$ & $1.07(0.34)$ & $0.60(0.13)$ & $6.59(2.68)$ \\
\hline $\begin{array}{l}\text { Mean outside } \\
(S D)\end{array}$ & $1.06(0.28)$ & $0.63(0.14)$ & $6.72(2.73)$ \\
\hline $\begin{array}{l}\text { |Mean } \\
\text { differencel }\end{array}$ & 0.01 & 0.03 & 0.13 \\
\hline$|t|$ & 0.23 & 1.02 & 0.30 \\
\hline$p$-value & 0.82 & 0.31 & 0.77 \\
\hline
\end{tabular}

FIGURE 2 Functional trait space generated from a principal coordinates analysis of species traits. Species codes are presented in Table 2

TABLE 3 Summary statistics and paired $t$-test results for functional dispersion, functional evenness, and functional richness for lakes inside versus outside of terrestrial protected areas (TPAs), inside versus bordering TPAs, and bordering versus outside of TPAs
TPAs and were rare (average CPUE: 0.003 and 0.076, respectively), whereas threespine stickleback was only sampled in a single lake bordering TPAs (CPUE: 0.250). In contrast, trout-perch Percopsis omiscomaycus
(Percopsidae), cisco Coregonus artedi (Salmonidae), and lake whitefish Coregonus clupeaformis (Salmonidae) showed the lowest functional rarity (Figure 5) and were clustered on the positive side of the first component, 
FIGURE 3 (a) Fitted generalised additive model for functional dispersion and species richness for lakes bordering, outside, and inside of terrestrial protected areas (TPAs). (b) Difference between fitted smooth functions (difference in trends; solid line) and approximate 95\% pointwise confidence intervals (shaded region) on this difference for functional dispersion and species richness between lake communities inside and outside of TPAs, (c) bordering and outside of TPAs, and (d) bordering and inside of TPAs
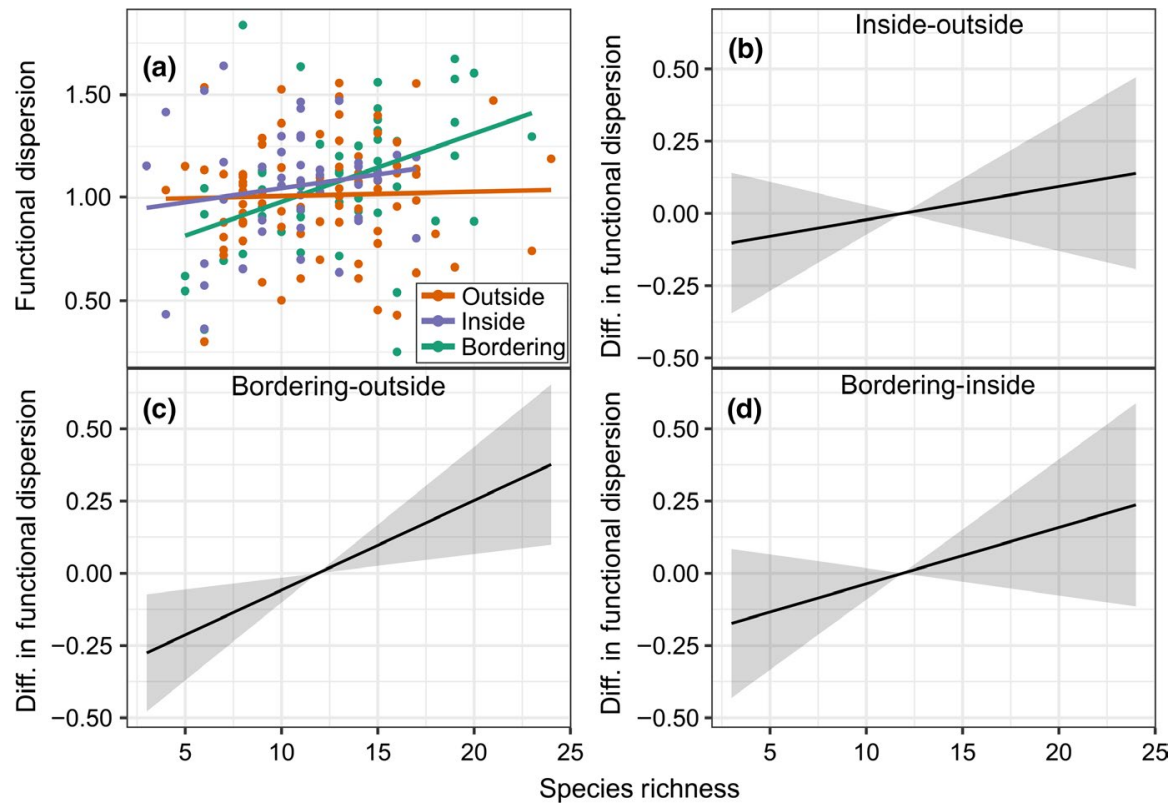

FIGURE 4 Functional distinctiveness $(a-c)$ and uniqueness $(d-f)$ across log-transformed species prevalence, log-transformed average maximum total length $(\mathrm{cm})$, and thermal preference groups
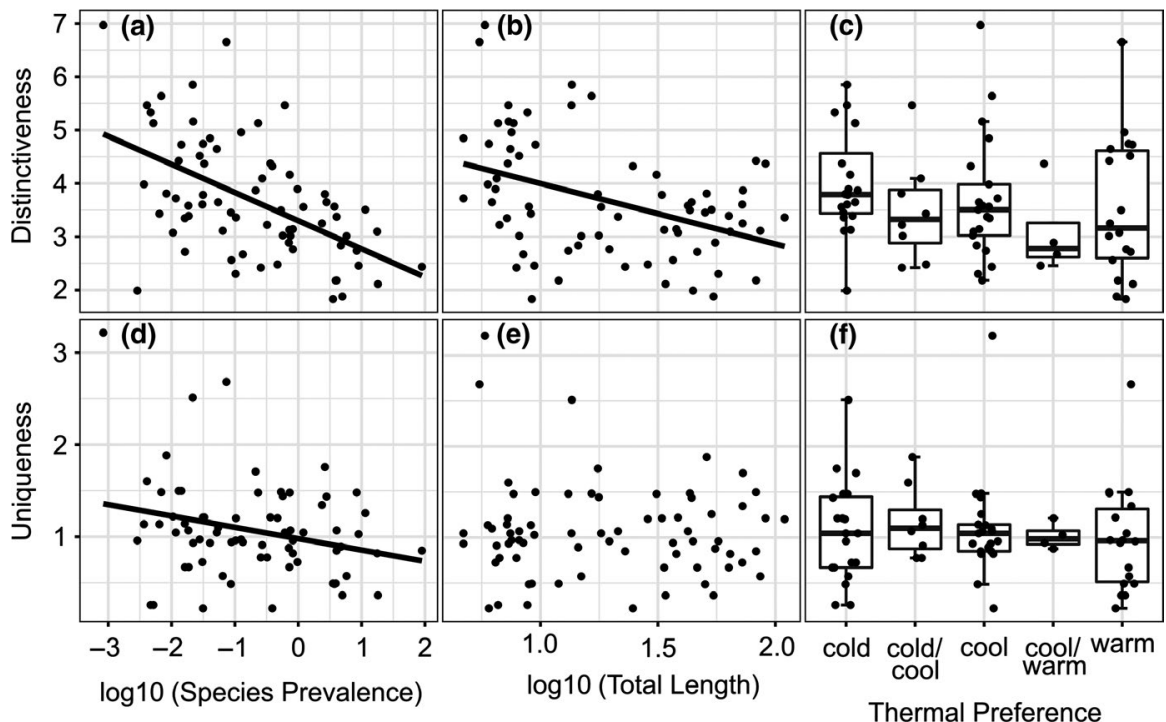

near the origin (Figure 2). Trout-perch, cisco, and lake whitefish were among the most abundant species and occurred across all lake types. There were no significant differences in uniqueness or distinctiveness across thermal preference groups (distinctiveness: $F_{4,66}=0.90, p=0.47$; uniqueness: $F_{4,66}=0.20, p=0.94$; Figure $\left.4 c, f\right)$.

\section{4 | DISCUSSION}

Similar to results based on taxonomic indices (Chu et al., 2018), we found few differences in functional diversity of lake fish communities inside, bordering, or outside TPAs. Of the differences we did find, our results indicated that lake fish communities inside TPAs had greater functional divergence than communities outside TPAs, regardless of species richness. This result indicates that, on average, abundant species in fish communities inside TPAs had more extreme (i.e. divergent) trait values than abundant species outside TPAs. According to the principle of limiting similarity (MacArthur \& Levins, 1967), species with limited functional overlap with the rest of an assemblage should increase in abundance within TPAs because they are less limited by competition than species with common functions. For example, Mouillot, Culioli, Pelletier, and Tomasini (2008) observed increases in the abundance of functionally original fishes after protection of a reserve in the Mediterranean Sea. In our study, the abundance distribution of species was more heavily skewed in lakes outside TPAs compared to lakes inside TPAs and fish communities inside TPAs also had greater Bray-Curtis dissimilarity than communities outside TPAs (by pairwise permutational analysis of variance, not shown), suggesting greater differences in community composition among lakes inside TPAs than outside. The greater abundances of generalist species in 
Bridle Shiner Threespine Stickleback Green Sunfish -

Brook Silverside Gizzard Shad Fathead Minnow Deepwater Sculpin -

Greater Redhorse Chinook Salmon Pumpkinseed -

Northern Sunfish -

Channel Catfish -

Brown Bullhead

Longnose Dace -

Mottled Sculpin -

Bluntnose Minnow -

Slimy Sculpin -

Blacknose Dace -

Lake Sturgeon -

Smallmouth Bass Brook Trout lowa Darter

Yellow Bullhead White Sucker Lake Trout -

Longnose Gar Creek Chub -

Blackchin ShinerJohnny Darter -

Brook Stickleback -

Common Shiner

Fallfish -

Central Mudminnow -

Banded Killifish -

Rainbow Trout

Rosyface ShinerRock Bass -

Ninespine SticklebackMimic Shiner Logperch Mooneye

Common Carp

Blacknose Shiner WalleyeSauger Black Crappie-

Muskellunge -

Golden Shiner

Northern Pearl Dace-

Spottail Shiner

Emerald Shiner -

Round Whitefish -

Largemouth Bass -

Shorthead Redhorse -

Silver Redhorse-

Rainbow Smelt -

Yellow Perch
Northern Redbelly Dace
GoldeyeGoldeye Northern Pike -
Longnose Sucker-

Lake Chub -

Trout-perch Lake Whitefish

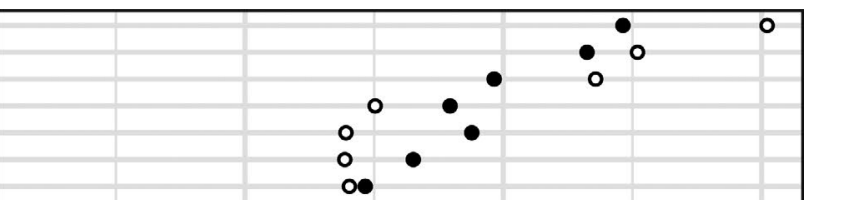

FIGURE 5 Functional rarity measures for 71 observed species. Species are ordered based on the average of the scaled and centred functional rarity measures (i.e. uniqueness, distinctiveness) across lake communities 
trait values, which are abundant inside TPAs are spilling over (e.g. from marine reserves; Roberts, Bohnsack, Gell, Hawkins, \& Goodridge, 2001) in to hydrologically connected lakes bordering TPAs leading to these patterns, but this hypothesis has yet to be tested directly.

From a species-specific perspective, our results indicate that smaller bodied species are characterised by the greatest functional distinctiveness, that is, they fill functionally unique roles in our study lakes. This makes intuitive sense given that smaller bodied species are inherently restricted by gape limitations and swimming capacity due to size alone. This result is in contrast with Lamothe, Alofs, et al. (2018), who found no differences in distinctiveness with average total body length across fishes in Ontario lakes; however, the habitat traits used in our study, namely depth and body size, are based on empirical measures from the field whereas Lamothe, Alofs, et al. (2018) used data based on literature sources, making comparisons difficult. Finally, our results confirmed expectations that the most prevalent species across the studied lakes had the lowest average functional distinctiveness and uniqueness, suggesting that common species possess a more generalist set of traits, forming an average ecological niche.

There are several potential reasons why we found few differences in functional diversity of lake fish communities inside, bordering, and outside TPAs. First, many of the lakes paired for the inside and outside TPA comparisons are in areas of low disturbance and where environmental conditions and anthropogenic stresses are similar across TPA boundaries (Chu et al., 2015, 2018). This homogeneity makes the benefits of protections implemented in most TPAs (OMNR, 2011) less noticeable or only obvious if and when stresses (e.g. forestry or industrial development) outside TPAs increase. Second, differences in functional diversity may not be detectable as a result of our study design. Pairing lakes based on ecologically relevant abiotic characteristics allowed us to examine the potential impact of TPAs while controlling for other factors that are known to impact functional diversity, but also limited our sample size. Third, functional diversity measures are influenced by which traits are included in their calculation (Cadotte, Carscadden, \& Mirotchnick, 2011). Here, we chose to include traits related to diet, substrate, depth, and reproduction to broadly encompass the ecological niche of fishes. Significant differences may have been observed had we defined trait space differently. Finally, sampling bias may have played a role in our inability to detect differences between lake communities. We found that the smallest species were the most functionally distinct, but these species are also least likely to be captured in the gill nets. Given their body sizes, they are not as likely as large-bodied species to encounter the nets (Minns, 1995) and they are susceptible to only the smallest mesh sizes (13- and 19-mm stretch mesh) used in the BsM protocol. The effects of size-based sampling could be magnified in abundanceweighted diversity metrics, but running our analysis with presence-absence data did not change our results.

Functional similarity of fish communities inside and outside TPAs suggests that lakes within designated TPAs capture representative samples of lake fish diversity and the services these fishes provide.
We suggest that functional diversity should be considered in future monitoring of these lake communities as a means to assess the effectiveness of protection for fish diversity. As fish species distributions and changes in relative abundance have already been observed with climate change, it will be particularly interesting to document how increasing lake temperatures impact functional diversity (Alofs, Jackson, \& Lester, 2014; Chu, Mandrak, \& Minns, 2005; Hansen, Read, Hansen, $\&$ Winslow, 2017). Based on our results, and those of Lamothe, Alofs, et al. (2018), there seems to be little relationship between functional rarity and thermal preference in Ontario lake fishes. However, we found that small-bodied species showed the greatest functional rarity and large, common species showed the most average functional niches. Of the 21 species in Ontario listed for protection under the federal Canadian Species at Risk Act (Government of Canada 2002) as Special Concern, Threatened, Endangered, or Extirpated, nine ( 43\%) have an average total length of $<10 \mathrm{~cm}$ (Holm et al., 2009); this includes bridle shiner and deepwater sculpin Myoxocephalus thompsonii (Cottidae), which were sampled in the studied lakes. Taken together, conservation of small-bodied species should be prioritised to maintain the functional diversity of Ontario lakes.

Almost $15 \%$ of the terrestrial landscape is protected (World Bank Group, 2019), yet few explicitly freshwater protected areas have been established worldwide (Saunders, Meeuwig, \& Vincent, 2002). Although we detected few differences in functional diversity, we encourage similar evaluations in high contrast areas where environmental conditions and stressors are distinct across TPA boundaries and in different types of freshwater ecosystems. For example, Wilkinson et al. (2018) found greater local species richness, greater functional richness, and no difference in functional divergence in protected streams in Borneo. This was driven by the presence of several endemic, specialist species in streams within protected areas, which is not consistent with our findings for lakes. More evaluations of the effectiveness of existing protected areas for freshwater ecosystems will improve our understanding of the benefits and shortcomings of them and inform the development of guidelines for freshwater protected area designs and for monitoring their ecosystem services and success in the future.

\section{ACKNOWLEDGMENTS}

This study would be impossible without the dozens of field crews sampling lakes as part of the OMNRF BsM Program. The authors would like to acknowledge and NSERC Visiting Fellowship with Fisheries and Oceans Canada for funding K.A.L. and have no conflicts of interest to declare.

\section{DATA AVAILABILITY STATEMENT}

Data available on request from the authors.

\section{ORCID}

Karl A. Lamothe (iD https://orcid.org/0000-0001-9875-8204 


\section{REFERENCES}

Abell, R., Thieme, M. L., Revenga, C., Bryer, M., Kottelat, M., Bogutskaya, N., ... Petry, P. (2008). Freshwater ecoregions of the world: a new map of biogeographic units for freshwater biodiversity conservation. BioScience, 58(5), 403-414. https://doi. org/10.1641/b580507

Alofs, K. M., Jackson, D. A., \& Lester, N. P. (2014). Ontario freshwater fishes demonstrate differing range-boundary shifts in a warming climate. Diversity \& Distributions, 20(2), 123-136. https://doi. org/10.1111/ddi.12130

Anderson, M. J. (2006). Distance-based tests for homogeneity of multivariate dispersion. Biometrics, 62(1), 245-253. https://doi. org/10.1111/j.1541-0420.2005.00440.x

Arthington, A. H., Dulvy, N. K., Gladstone, W., \& Winfield, I. J. (2016). Fish conservation in freshwater and marine realms: Status, threats and management. Aquatic Conservation: Marine and Freshwater Ecosystems, 26(5), 838-857. https://doi.org/10.1002/aqc.2712

Aylward, B., Bandyopadhyay, J., Belausteguigotia, J. C., Börkey, P., Cassar, A., Meadors, L., ... Voutchkov, N. (2005). Freshwater ecosystem services. In R. Rijsberman, R. Costanza \& P. Jacobi (review Eds.), Ecosystems and human well-being: Current state and trends, Volume 1. Millennium ecosystem assessment (pp. 213-255). Washington, DC: Island Press.

Britton, A. W., Day, J. J., Doble, C. J., Ngatunga, B. P., Kemp, K. M., Carbone, C., \& Murrell, D. J. (2017). Terrestrial-focused protected areas are effective for conservation of freshwater fish diversity in Lake Tanganyika. Biological Conservation, 212, 120-129. https://doi. org/10.1016/j.biocon.2017.06.001

Bruner, A. G., Gullison, R. E., Rice, R. E., \& de Fonseca, G. A. B. (2001). Effectiveness of parks in protecting tropical biodiversity. Science, 291(5501), 125-128. https://doi.org/10.1126/science.291.5501.125

Buisson, L., Grenouillet, G., Villéger, S., Canal, J., \& Laffaile, P. (2013). Toward a loss of functional diversity in stream fish assemblages under climate change. Global Change Biology, 19(2), 387-400. https ://doi.org/10.1111/gcb.12056

Burkhead, N. M. (2012). Extinction rates in North American freshwater fishes, 1900-2010. BioScience, 62(9), 798-808. https://doi. org/10.1525/bio.2012.62.9.5

Cadotte, M. W., Carscadden, K., \& Mirotchnick, N. (2011). Beyond species: Functional diversity and the maintenance of ecological processes and services. Journal of Applied Ecology, 48, 1079-1087. https ://doi.org/10.1111/j.1365-2664.2011.02048.x

Cardinale, B. J., Duffy, J. E., Gonzalez, A., Hooper, D. U., Perrings, C., Venail, P., ... Naeem, S. (2012). Biodiversity loss and its impact on humanity. Nature, 486, 59-67. https://doi.org/10.1038/natur e11148

Carpenter, S. R., Stanley, E. H., \& Vander Zanden, M. J. (2011). State of the world's freshwater ecosystems: Physical, chemical, and biological changes. Annual Review of Environment and Resources, 36, 75-99. https://doi.org/10.1146/annurev-environ-021810-094524

Chu, C., Ellis, L., \& de Kerckhove, D. T. (2018). The effectiveness of terrestrial protected areas for lake fish community conservation. Conservation Biology, 32(3), 607-618. https://doi.org/10.1111/ cobi.13034

Chu, C., Lester, N. P., Giacomini, H. C., Shuter, B. J., \& Jackson, D. A. (2016). Catch-per-unit-effort and size spectra of lake fish assemblages reflect underlying patterns in ecological conditions and anthropogenic activities across regional and local scales. Canadian Journal of Fisheries and Aquatic Sciences, 73(4), 535-546. https://doi. org/10.1139/cjfas-2015-0150

Chu, C., Mandrak, N. E., \& Minns, C. K. (2005). Potential impacts of climate change on the distributions of several common and rare freshwater fishes in Canada. Diversity \& Distributions, 11(4), 299-310. https://doi. org/10.1111/j.1366-9516.2005.00153.x
Chu, C., Minns, C. K., Lester, N. P., \& Mandrak, N. E. (2015). An updated assessment of human activities, the environment, and freshwater fish biodiversity in Canada. Canadian Journal of Fisheries and Aquatic Sciences, 72(1), 135-148. https://doi.org/10.1139/cjfas-2013-0609

Coker, G. A., Portt, C. B., \& Minns, C. K. (2001). Morphological and ecological characteristics of Canadian freshwater fishes. Canada Manuscript Report of Fisheries and Aquatic Sciences No. 2554, iv +89.

Collen, B., Whitton, F., Dyer, E. E., Baillie, J. E. M., Cumberlidge, N., Darwall, W. R. T., ... Böhm, M. (2014). Global patterns of freshwater species diversity, threat and endemism. Global Ecology and Biogeography, 23(1), 40-51. https://doi.org/10.1111/geb.12096

Dextrase, A. J., \& Mandrak, N. E. (2006). Impacts of alien invasive species on freshwater fauna at risk in Canada. Biological Invasions, 8(1), 13-24. https://doi.org/10.1007/s10530-005-0232-2

Dudgeon, D. (2014). Threats to freshwater biodiversity in a changing world. Handbook of global environmental pollution (Vol. 1). New York, NY: Springer.

Dudgeon, D., Arthington, A. H., Gessner, M. O., Kawabata, Z. I., Knowler, D. J., Lévêque, C., ... Sullivan, C. A. (2006). Freshwater biodiversity: Importance, threats, status and conservation challenges. Biological Reviews, 81(2), 163-182. https://doi.org/10.1017/s146479310 5006950

Dudley, N. (Ed.) (2008). Guidelines for applying protected area management categories (p. 86). Gland, Switzerland: IUCN. With: Stolton, S., Shadie P., \& Dudley, N. (2013). IUCN WCPA Best Practice Guidance on Recognising Protected Areas and Assigning Management Categories and Governance Types, Best Practice Protected Area Guidelines Series No. 21, Gland, Switzerland: IUCN.

Dugan, H. A., Bartlett, S. L., Burke, S. M., Doubek, J. P., Krivak-Tetley, F. E., Skaff, N. K., ... Weathers, K. C. (2017). Salting our freshwater lakes. PNAS, 114(17), 4453-4458. https://doi.org/10.1073/ pnas. 1620211114

Eakins, R. J. (2017). Ontario freshwater fishes life history database. (Version 4.74). Online database. Retrieved from http://www.ontariofishes.ca

Eerkes-Medrano, D., Thompson, R. C., \& Aldridge, D. C. (2015). Microplastics in freshwater systems: A review of the emerging threats, identification of knowledge gaps and prioritisation of research needs. Water Research, 75, 63-82. https://doi.org/10.1016/j. watres.2015.02.012

Environment and Climate Change Canada (2017a). Water and the environment: Frequently asked questions. Retrieved from www.canada. ca/en/environment-climate-change/services/water-overview/frequ ently-asked-questions.html. Accessed 03292018.

Environment and Climate Change Canada (2017b). Canadian environmental sustainability indicators: Canada's protected areas. Consulted on Month day, year. Retrieved from www.ec.gc.ca/indicateurs-indicators/defau It.asp?:xml:lang=en\&n = 478A1D3D-1. Accessed 02052018 .

Frimpong, E. A., \& Angermeier, P. L. (2009). FishTraits: A database of ecological and life-history traits of freshwater fishes of the United States. Fisheries, 34(10), 487-495. https://doi. org/10.1577/1548-8446-34.10.487

Givan, O., Parravicini, V., Kulbicki, M., \& Belmaker, J. (2017). Trait structure reveals the processes underlying fish establishment in the Mediterranean. Global Ecology and Biogeography, 26(2), 142-153. https://doi.org/10.1111/geb.12523

Government of Canada. (1985a). Canada water act. R.S.C., 1985, c. C-11. Available from https://laws-lois.justice.gc.ca/PDF/C-11.pdf

Government of Canada. (1985b). Fisheries act. R.S.C., 1985, c. F-14. Available from https://laws-lois.justice.gc.ca/PDF/F-14.pdf

Government of Canada. (2002). Canada species at risk act. S.C. 2002, c, 29. Available from https://laws-lois.justice.gc.ca/PDF/S-15.3.pdf

Gray, C. L., Hill, S. L. L., Newbold, T., Hudson, L. N., Börger, L., Contu, S., ... Scharlemann, J. P. W. (2016). Local biodiversity is higher inside than outside terrestrial protected areas worldwide. Nature Communications, 7, 12306. https://doi.org/10.1038/ncomms12306 
Grenié, M., Denelle, P., Tucker, C., Munoz, F., \& Violle, C. (2017). funrar: An R package to characterize functional rarity. Diversity \& Distributions, 23(12), 1365-1371. https://doi.org/10.1111/ddi.12629

Hansen, G. J. A., Read, J. S., Hansen, J. F., \& Winslow, L. A. (2017). Projected shifts in fish species dominance in Wisconsin lakes under climate change. Global Change Biology, 23(4), 1463-1476. https://doi. org/10.1111/gcb.13462

Harrison, I. J., Green, P. A., Farrell, T. A., Juffe-Bignoli, D., Sáenz, L., \& Vörösmarty, C. J. (2016). Protected areas and freshwater provisioning: A global assessment of freshwater provision, threats and management strategies to support human water security. Aquatic Conservation: Marine and Freshwater Ecosystems, 26(S1), 103-120. https://doi.org/10.1002/aqc.2652

Holm, E., Mandrak, N., \& Burridge, M. (2009). The ROM field guide to freshwater fishes of Ontario. Toronto, ON: Royal Ontario Museum.

Hubálek, Z. (1982). Coefficients of association and similarity, based on binary (presence-absence) data: An evaluation. Biological Reviews, 57(4), 669-689. https://doi.org/10.1111/j.1469-185x.1982.tb003 $76 . x$

IUCN, UNEP-WCMC [International Union for Conservation of Nature - United Nations Environment World Conservation Monitoring Centre]. (2016). The world database on protected areas (WDPA). Cambridge, UK: UNEP World Conservation Monitoring Centre. Retrieved from www.protectedplanet.net [accessed January 2016].

Jackson, M. C., Loewen, C. J., Vinebrooke, R. D., \& Chimimba, C. T. (2016). Net effects of multiple stressors in freshwater ecosystems: A meta-analysis. Global Change Biology, 22(1), 180-189. https://doi. org/10.1111/gcb.13028

Laliberté, E., \& Legendre, P. (2010). A distance-based framework for measuring functional diversity from multiple traits. Ecology, 91(1), 299-305. https://doi.org/10.1890/08-2244.1

Laliberté, E., Legendre, P., \& Shipley, B. (2014). FD: Measuring functional diversity from multiple traits, and other tools for functional ecology. $\mathrm{R}$ package version 1.0-12. Retrieved from https://cran.r-project.org/ web/packages/FD/index.html

Laliberté, E., Wells, J. A., DeClerck, F., Metcalfe, D. J., Catterall, C. P., Queiroz, C., ... Mayfield, M. M. (2010). Land-use intensification reduces plan functional redundancy and response diversity in plant communities. Ecology Letters, 13(1), 76-86. https://doi. org/10.1111/j.1461-0248.2009.01403.x

Lamothe, K. A., Alofs, K. M., Jackson, D. A., \& Somers, K. M. (2018). Functional diversity and redundancy of freshwater fish communities across biogeographic and environmental gradients. Diversity \& Distributions, 24(11), 1612-1626. https://doi.org/10.1111/ddi.12812

Lamothe, K. A., Drake, D. A. R., Pitcher, T. E., Broome, J. E., Dextrase, A. J., Gillespie, A., ... Vachon, N. (In press). Reintroduction of fishes in Canada: A review of research progress for SARA-listed fishes. Environmental Reviews. https://doi.org/10.1139/er-2019-0010

Lamothe, K. A., Jackson, D. A., \& Somers, K. M. (2018). Long-term directional trajectories among lake crustacean zooplankton communities and water chemistry. Canadian Journal of Fisheries and Aquatic Sciences, 75(11), 1926-1939. https://doi.org/10.1139/ cjfas-2017-0518

Legendre, P., \& Gallagher, E. (2001). Ecologically meaningful transformations for ordination of species data. Oecologia, 129(2), 271-280. https ://doi.org/10.1007/s004420100716

Lester, N. P., Marshall, T. R., Armstrong, K., Dunlop, W. I., \& Ritchie, B. (2003). A broad-scale approach to management of Ontario's recreational fisheries. North American Journal of Fisheries Management, 23(4), 1312-1328. https://doi.org/10.1577/m01-230am

MacArthur, R., \& Levins, R. (1967). The limiting similarly, convergence, and divergence of coexisting species. The American Naturalist, 101(921), 377-385. https://doi.org/10.1086/282505

Mandrak, N. E. (1995). Biogeographic patterns of fish species richness in Ontario lakes in relation to historical and environmental factors.
Canadian Journal of Fisheries and Aquatic Sciences, 52(7), 1462-1474. https://doi.org/10.1139/f95-141

Mason, N. W. H., Mouillot, D., Lee, W. G., \& Wilson, J. B. (2005). Functional richness, functional evenness and functional divergence: The primary components of functional diversity. Oikos, 111(1), 112118. https://doi.org/10.1111/j.0030-1299.2005.13886.x

Mason, N. W. H., Richardson, S. J., Peltzer, D. A., Wardle, D. A., de Bello, F., \& Allen, R. B. (2012). Changes in co-existence mechanisms along a long-term soil chronosequence revealed by functional trait diversity. Journal of Ecology, 100(3), 678-689. https://doi. org/10.1111/j.1365-2745.2012.01965.x

Micheli, F., \& Halpern, B. S. (2005). Low functional redundancy in coastal marine assemblages. Ecology Letters, 8(4), 391-400. https://doi. org/10.1111/j.1461-0248.2005.00731.x

Minns, C. K. (1995). Allometry of home range size in lake and river fishes. Canadian Journal of Fisheries and Aquatic Sciences, 52(7), 1499-1508. https://doi.org/10.1139/f95-144

Mouchet, M. A., Villéger, S., Mason, N. W. H., \& Mouillot, D. (2010). Functional diversity measures: An overview of their redundancy and their ability to discriminate community assembly rules. Functional Ecology, 24(4), 867-876. https://doi. org/10.1111/j.1365-2435.2010.01695.x

Mouillot, D., Culioli, J. M., Pelletier, D., \& Tomasini, J. A. (2008). Do we protect biological originality in protected areas? A new index and an application to the Bonifacio Strait Natural Reserve. Biological Conservation, 141, 1569-1580. https://doi.org/10.1016/j. biocon.2008.04.002

Mouillot, D., Graham, N. A. J., Villéger, S., Mason, N. W. H., \& Bellwood, D. R. (2013). A functional approach reveals community responses to disturbance. Trends in Ecology \& Evolution, 28(3), 167-177. https://doi. org/10.1016/j.tree.2012.10.004

Mouillot, D., Villéger, S., Parravicini, V., Kulbicki, M., Arias-González, J. E., Bender, M., ... Bellwood, D. R. (2014). Functional over-redundancy and high functional vulnerability in global fish faunas on tropical reefs. PNAS, 111(38), 13757-13762. https://doi.org/10.1073/ pnas.1317625111

Mouillot, D., Villéger, S., Scherer-Lorenzen, M., \& Mason, N. W. H. (2011). Functional structure of biological communities predicts ecosystem multifunctionality. PLoS ONE, 6(3), e17476. https://doi.org/10.1371/ journal.pone.0017476

Myers, B. J. E., Lynch, A. J., Bunnell, D. B., Chu, C., Falke, J. A., Kovach, R. P., ... Paukert, C. P. (2017). Global synthesis of the projected and documented effects of climate change on inland fishes. Reviews in Fish Biology and Fisheries, 27(2), 339-361. https://doi.org/10.1007/ s11160-017-9476-z

Nõges, P., Argillier, C., Borja, Á., Garmendia, J. M., Hanganu, J., Vit, K., ... Birk, S. (2016). Quantified biotic and abiotic responses to multiple stress in freshwater, marine and ground waters. Science of the Total Environment, 540, 43-52. https://doi.org/10.1016/j.scito tenv.2015.06.045

Ochiai, A. (1957). Zoogeographic studies on the soleoid fishes found in Japan and its neighbouring regions. Bulletin of the Japanese Society of Scientific Fisheries (Nippon Suisan Gakkaishi), 22(9), 526-530. https:// doi.org/10.2331/suisan.22.522

Oksanen, J., Blanchet, F. G., Friendly, M., Kindt, R., Legendre, P., McGlinn, D., ... Wagner, H. (2018). vegan: Community ecology package. R package version 2.5-2. Retrieved from https://cran.r-project.org/web/ packages/vegan/index.html

OMNR [Ontario Ministry of Natural Resources] (2011). State of Ontario's protected areas report. Peterborough, ON, Canada: Ontario Ministry of Natural Resources.

OMNRF [Ontario Ministry of Natural Resources and Forestry]. (2015). Ontario's provincial fish strategy. Peterborough, ON, Canada: Fisheries Policy Section, Species Conservation Policy Branch, Ontario Ministry of Natural Resources and Forestry. 
Peres-Neto, P. R., Jackson, D. A., \& Somers, K. M. (2003). Giving meaningful interpretation to ordination axes: Assessing loading significance in principal component analysis. Ecology, 84(9), 2347-2363. https://doi.org/10.1890/00-0634

Peres-Neto, P. R., Jackson, D. A., \& Somers, K. M. (2005). How many principal components? stopping rules for determining the number of non-trivial axes revisited. Computational Statistics \& Data Analysis, 49(4), 974-997. https://doi.org/10.1016/j.esda.2004.06.015

Pimm, S. L., Jenkins, C. N., Abell, R., Brooks, T. M., Gittleman, J. L., Joppa, L. N., ... Sexton, J. O. (2014). The biodiversity of species and their rates of extinction, distribution, and protection. Science, 344(6187), 1246752. https://doi.org/10.1126/science.1246752

Poesch, M. S., Chavarie, L., Chu, C., Pandit, S. N., \& Tonn, W. (2016). Climate change impacts on freshwater fishes: A Canadian perspective. Fisheries, 41(7), 385-391. https://doi.org/10.1080/03632 415.2016.1180285

R Core Team (2018). R: A language and environment for statistical computing. Vienna, Austria: R Foundation for Statistical Computing. Retrieved from http://www.R-project.org/

Reid, A. J., Carlson, A. K., Creed, I. F., Eliason, E. J., Gell, P. A., Johnson, P. T. J., ... Cooke, S. J. (2019). Emerging threats and persistent conservation challenges for freshwater biodiversity. Biological Reviews, 94, 849-873. https://doi.org/10.1111/brv.12480

Roberts, C. M., Bohnsack, J. A., Gell, F., Hawkins, J. P., \& Goodridge, R. (2001). Effects of marine reserves on adjacent fisheries. Science, 294 1920-1923. https://doi.org/10.1126/science.294.5548.1920

Rose, N. L., Yang, H., Turner, S. D., \& Simpson, G. L. (2012). An assessment of the mechanisms for the transfer of lead and mercury from atmospherically contaminated organic soils to lake sediments with particular reference to Scotland, UK. Geochemica et Cosmochimica Acta, 82, 113-135. https://doi.org/10.1016/j.gca.2010.12.026

Sagouis, A., Jabot, F., \& Argillier, C. (2016). Taxonomic versus functional diversity metrics: How do fish communities respond to anthropogenic stressors in reservoirs? Ecology of Freshwater Fish, 26(4), 621635. https://doi.org/10.1111/eff.12306

Sandstrom, S., Rawson, M., \& Lester, N. (2011). Manual of instructions for broad-scale fish community monitoring; using North American (NA1) and Ontario small mesh (ON2) gillnets. Version 2011.1 (p. 30). Peterborough, ON, Canada: Ontario Ministry of Natural Resources. appendices.

Saunders, D. L., Meeuwig, J. J., \& Vincent, A. C. J. (2002). Freshwater protected areas: Strategies for conservation. Conservation Biology, 16(1), 30-41. https://doi.org/10.1046/j.1523-1739.2002.99562.x

Schindler, D. W. (2001). The cumulative effects of climate warming and other human stresses on Canadian freshwaters in the new millennium. Canadian Journal of Fisheries and Aquatic Sciences, 58(1), 18-29. https://doi.org/10.1139/f00-179

Smith, V. H., Tilman, G. D., \& Nekola, J. C. (1999). Eutrophication: Impacts of excess nutrient inputs on freshwater, marine, and terrestrial ecosystems. Environmental Pollution, 100(1-3), 179-196. https://doi. org/10.1016/s0269-7491(99)00091-3

Strecker, A. L., Olden, J. D., Whittier, J. B., \& Paukert, C. P. (2011). Defining conservation priorities for freshwater fishes according to taxonomic, functional, and phylogenetic diversity. Ecological Applications, 21(8), 3002-3013. https://doi.org/10.1890/11-0599.1
Tan, M., \& Armbruster, J. W. (2018). Phylogenetic classification of extant genera of fishes of the order Cypriniformes (Teleostei: Ostariophysi). Zootaxa, 4476(1), 006-039. https://doi.org/10.11646/zoota xa.4476.1.4

Tedesco, P. A., Beauchard, O., Bigorne, R., Blanchet, S., Buisson, L., Conti, L., ... Oberdorff, T. (2017). A global database on freshwater fish species occurrence in drainage basins. Scientific Data, 4, 170141. https:// doi.org/10.1038/sdata.2017.141

Toussaint, A., Charpin, N., Beachard, O., Grenouillet, G., Oberforff, T., Tedesco, P. A., ... Villéger, S. (2018). Non-native species led to marked shifts in functional diversity of the world freshwater fish faunas. Ecology Letters, 21(11), 1649-1659. https://doi.org/10.1111/ ele.13141

Villéger, S., Mason, N. W. H., \& Mouillot, D. (2008). New multidimensional functional diversity indices for a multifaceted framework in functional ecology. Ecology, 89(8), 2290-2301. https://doi. org/10.1890/07-1206.1

Violle, C., Thuiller, W., Mouquet, N., Munoz, F., Kraft, N. J. B., Cadotte, M. W., ... Mouillot, D. (2017). Functional rarity: The ecology of outliers. Trends in Ecology \& Evolution, 32(5), 356-367. https://doi. org/10.1016/j.tree.2017.02.002

Wickham, H. (2009). ggplot2: Elegant graphics for data analysis. New York, NY: Springer-Verlag.

Wilkinson, C. L., Yeo, D. C., Tan, H. H., Fikri, A. H., \& Ewers, R. M. (2018). Land-use change is associated with a significant loss of freshwater fish species and functional richness in Sabah, Malaysia. Biological Conservation, 222, 164-171. https://doi.org/10.1016/j. biocon.2018.04.004

Winemiller, K. O., Fitzgerald, D. B., Bower, L. M., \& Pianka, E. R. (2015). Functional traits, convergent evolution, and period tables of niches. Ecology Letters, 18(8), 737-751. https://doi.org/10.1111/ele.12462

Wood, S. N. (2004). Stable and efficient multiple smoothing parameter estimation for generalized additive models. Journal of the American Statistical Association, 99(467), 673-686. https://doi. org/10.1198/016214504000000980

Wood, S. N. (2006). Generalized additive models: An introduction with $R$. Boca Raton, FL: CRC Press, Chapman \& Hall.

World Bank Group (2019). Terrestrial protected areas (\% of total land area). Retrieved from https://data.worldbank.org/indicator/ER.LND.PTLD. ZS. Accessed: 012819.

\section{SUPPORTING INFORMATION}

Additional supporting information may be found online in the Supporting Information section at the end of the article.

How to cite this article: Lamothe KA, Alofs KM, Chu C. Evaluating functional diversity conservation for freshwater fishes resulting from terrestrial protected areas. Freshw Biol. 2019;64:2057-2070. https://doi.org/10.1111/fwb.13395 